\title{
Is there linkage between supernumerary teats in cattle and BTA3
} markers? ${ }^{1}$

\begin{abstract}
Summary
From 1997 to 19991005 new born German Holstein calves were investigated for the incidence of supernumerary teats. Age at inspection varied from 1 to 4 weeks. In total 110 affected calves (20 male and 90 female) and their 21 sires were genotyped for five chromosome 3 microsatellites. The average size of half-sib families was 5.2 ranging from 2 to 17. A non-parametric multipoint linkage analysis showed no evidence for linkage.
\end{abstract}

Key Words: hyperthelia, polythelia, hypermastia, bos taurus

\section{Zusammenfassung}

Titel der Arbeit: Sind überzählige Zitzen beim Rind und BTA3-Marker gekoppelt ?

Das Auftreten von überzähligen Zitzen wurde an 1005 Kälbern der Rasse Deutsche Holstein in den Jahren 1997 bis 1999 in einem Alter von 1 bis 4 Wochen untersucht. Insgesamt 110 Kälber (20 männliche und 90 weibliche) mit überzähligen Zitzen und ihre 21 Väter wurden für fünf Mikrosatelliten auf Chromosom 3 typisiert. Die durchschnittliche Größe dieser Halbgeschwisterfamilien lag bei 5,2 und schwankte von 2 bis 17. Eine nichtparametrische Kopplungsanalyse zeigte kein signifikantes Ergebnis.

Schlüsselwörter: Hyperthelie, Polythelie, Hypermastie, Bos taurus

\section{Introduction}

The occurrence of supernumerary teats (hyperthelia) has ben observed in several species. In humans (URBANI and BETTI, 1996), sheep (VAINIKAINEN, 1945), guinea pigs (GOERTZEN and IBSEN, 1951), and mice (HOWARD and GUSTERSON, 2000) single gene dominant/recessive inheritance seems to be likely. In cattle, however, the pattern of penetrance must either be more complex, if a single gene is responsible for the trait (BRKA et al., 2000) or the inheritance is oligo- or polygenic. It can be expected that mapping experiments may add new insights into the genetics of bovine hyperthelia.

A second experiment (manuscript in preparation) showed weak evidence for linkage on BTA3. The aim of this study was to verify this result with independent families by genotyping affected half-sibs and their sires for five BTA3 microsatellite markers.

\section{Materials and methods}

\section{Animals and phenotypes}

From 1997 to 19991005 new born German Holstein calves from 29 sires were examined for the occurrence of supernumerary teats. Age of inspection varied from

\footnotetext{
${ }^{1}$ This work was supported by the Schaumann Stiftung
} 
one to four weeks. All calves were from one single farm. Supernumerary teats were diagnosed for 133 calves, 26 male and 107 female. The phenotype of all sires was unknown. After exclusion of 15 calves with wrong paternity and eight families with only one affected animal 110 calves from 21 sires (20 males and 90 females) remaind for analysis. The average number of affected half-sibs per sire was 5.2 and ranged from 2 to 17.

\section{Tissue samples and marker typing}

Blood samples were collected from all calves (and one natural service sire) at the day of inspection, stored in 9-ml EDTA-monovettes and deep frozen at $-20{ }^{\circ} \mathrm{C}$. A $0.25-\mathrm{ml}$ semen straw was available for each artificial insemination sire. For DNA isolation from blood samples the Puregene Blood Isolation Kit (GENTRA SYSTEMS, Inc. USA) was used, the protocol for DNA isolation from semen was as described by XU (1997). All affected calves and their sires were genotyped for markers BMS871, BMS2904, BMS482, INRA006 (KAPPES et al., 1997), and BovFCGRI1 (BISHOP et al., 1994). Details of PCR amplification are given in BRKA (2001). Genotyping was done on a A.L.F. (Automated Laser Fluorescence Detection System, Pharmacia) automatic sequencer. All genotypes were stored in the ADRDB database (REINSCH, 1999) and checked for typing errors.

\section{Statistical analysis}

Marker allele frequencies were estimated by maximum likelihood using the following log-likelihood function:

$$
\begin{gathered}
\ln L=\sum_{i=1}^{n} n_{i} \ln p_{i}+\sum_{i=1}^{n} \sum_{j=i+1}^{n} \frac{1}{2} n_{i j} \ln \left(p_{i}+p_{j}\right) \\
\text { with, } p_{n}=1-\sum_{i=1}^{n-1} p_{i}
\end{gathered}
$$

where $\mathrm{n}$ is the number of alleles at the marker considered, $\mathrm{n}_{\mathrm{i}}$ is the number of the $\mathrm{i}$-th allele from founder animals (i.e. either from founder sires or unequivocally descending from unknown dams), $\mathrm{n}_{\mathrm{ij}}$ is the number of half-sibs which share the same heterozygous genotype with their sire.

A non-parametric multipoint linkage analysis was performed, using the estimated marker allele frequencies and the ALLEGRO software (GUDBJARTSSON and JONASSON, 1999). Some of the half-sib families were connected through a common grandsire. Due to software limitations all half-sib families had however to be treated as unrelated. The NPL score was used as a test statistic (KRUGLYAK, 1996). Map distances (Table 1) were taken from THOMSEN et al., (2000).

\section{Results and discussion}

The number of marker alleles varied from three to seven and the number of informative meioses per marker was between 32 and 77 (Table 1).

Estimates of allele frequencies are given in Table 2. Markers INRA006, BMS2904 and BovFCGRI1 each showed one single allele with large frequency (from 0.62 to 0.81), 
whilest microsatellites BMS482 and BMS871 showed a more equal distribution of marker alleles.

Table 1

Number of alleles, number of informative meioses, and map position of used microsatellites (Anzahl Allele, Anzahl informativer Meiosen und Position der verwendeten Mikrosatelliten)

\begin{tabular}{lccc}
\hline Locus & Number of alleles & $\begin{array}{c}\text { Number of } \\
\text { Informative meioses }\end{array}$ & Map position \\
\hline BMS871 & 4 & 77 & 0.0 \\
INRA006 & 3 & 32 & 16.6 \\
BMS2904 & 3 & 39 & 21.9 \\
BMS482 & 7 & 74 & 28.4 \\
BovFCGRI1 & 4 & 76 & 29.7 \\
\hline
\end{tabular}

Table 2

Frequencies of marker alleles. In brackets the allele length in base pairs (Häufigkeiten der Markerallele. In Klammern die Allellänge in Basenpaaren)

\begin{tabular}{|c|c|c|c|c|c|c|c|}
\hline Marker & Allele 1 & Allele 2 & Allele 3 & Allele 4 & Allele 5 & Allele 6 & Allele 7 \\
\hline BMS871 & $\begin{array}{c}0.08 \\
(111)\end{array}$ & $\begin{array}{c}0.41 \\
(113)\end{array}$ & $\begin{array}{c}0.41 \\
(115)\end{array}$ & $\begin{array}{c}0.10 \\
(125)\end{array}$ & & & \\
\hline INRA006 & $\begin{array}{c}0.81 \\
(107)\end{array}$ & $\begin{array}{c}0.08 \\
(113)\end{array}$ & $\begin{array}{c}0.11 \\
(115)\end{array}$ & & & & \\
\hline BMS2904 & $\begin{array}{l}0.71 \\
(87)\end{array}$ & $\begin{array}{l}0.22 \\
(89)\end{array}$ & $\begin{array}{l}0.07 \\
(91)\end{array}$ & & & & \\
\hline BMS482 & $\begin{array}{c}0.11 \\
(147)\end{array}$ & $\begin{array}{c}0.08 \\
(149)\end{array}$ & $\begin{array}{c}0.08 \\
(153)\end{array}$ & $\begin{array}{c}0.22 \\
(155)\end{array}$ & $\begin{array}{c}0.08 \\
(159)\end{array}$ & $\begin{array}{c}0.08 \\
(161)\end{array}$ & $\begin{array}{c}0.35 \\
(163)\end{array}$ \\
\hline BovFCGRI1 & $\begin{array}{c}0.62 \\
(190)\end{array}$ & $\begin{array}{c}0.22 \\
(192)\end{array}$ & $\begin{array}{c}0.09 \\
(194)\end{array}$ & $\begin{array}{c}0.07 \\
(196)\end{array}$ & & & \\
\hline
\end{tabular}

The NPL score for non-parametric linkage showed only small values between -0.4786 and 0.0337 for the various map positions, and did not reach significance (error probabilities between 0.4369 and 0.6901 ).

Linkage with markers in the investigated $30 \mathrm{cM}$-region on chromosome 3 could thus not be verified. Possible reasons are a false positive result in the study mentioned above, genetic heterogenity (different genes segregating in different families), or too few heterozygous sires represented in the experiment. Mapping of genes responsible for hyperthelia in cattle therefore remains a still unsolved problem.

\section{References}

BISHOP, M. D.; KAPPES, S. M.; KEELE, J. W.; STONE, R. T.; SUNDEN, S. L. F.; HAWKINS, G. A.; SOLINAS-TOLDO, S.; FRIES, R.; GROSZ, M. D.; YOO, J. ; BEATTIE, C. W. B.:

A genetic linkage map for cattle. Genetics, 136 (1994), 619-639

BRKA, M.; REINSCH, N.; KALM, E.:

Determination of the inheritance pattern of hyperthelia in cattle by maximum likelihood analysis. BRKA, M.: Journal of Animal Breeding and Genetics, 117 (2000), 425-431

Analysen zur Vererbung überzähliger Zitzen beim Rind. Christian-Albrechts-Universität, Kiel, Germany, Thesis, 2001

GOERTZEN, B. L., IBSEN, H. L.:

Supernumerary mammae in guinea pigs. J. Hered., 42 (1951), 307-311

GUDBJARTSSON, F. D.; JONASSON, K.:

Allegro manual, version 1.1, Decode Genetics, Reykjavik, Iceland, 1999

HOWARD, B. A.; GUSTERSON, B. A.:

The characterisation of a mouse mutant that displays abnormal mammary gland development. Mamm. Genome, 11 (2000), 234-237 
KAPPES , S. M.; KEELE, J. W.; STONE, R. T.; MCGRAW, R. A.; SONSTEGARD, T. S.; SMITH, T. P. L.; LOPEZ-CORRALES, N. L.; BEATTIE, C. W.:

A second generation linkage map of the bovine genome. Genome Research, 7 (1997), 235-249

KRUGLYAK, L.; DALY, M. J.; REEVE-DALY, M. P.; LANDER, E. S.:

Parametric and Nonparametric Linkage Analysis: A Unified Multipoint Approach. Am. J. Hum. Genet., 58 (1996), 1347-1363

REINSCH, N.:

A multiple-species, multiple-project database for genotypes at codominant loci. Journal of Animal Breeding and Genetics, 116 (1999), 425-435

THOMSEN, H.; REINSCH, N.; XU, N.; LOOFT, C.; GRUPE, S.; KÜHN, C.; BROCKMANN, G.A.;

SCHWERIN, M.; LEYHE, B.; HIENDLEDER, S.; ERHARDT, G.; MEDJUGORAC, I., RUSS, I., FÖRSTER, M., BRENIG, B., REINHARD, F., REENTS, R., BLÜMEL, J.; AVERDUNK, G.; KALM, E. :

A male bovine linkage map for the ADR granddaughter design. Journal of Animal Breeding and Genetics, 117 (2000), 289-306

URBANI, C. E.; BETTI, R.:

Accessory Mammary Tissue in Clinical Practice. McGraw-Hill Libri Italia srl, Piazza Emilia, Milano, Italy, 1996

VAINIKAINEN, V.:

On the heritability of supernumerary nipples in Finnish home-bred sheep. Maataloustieteellinen XU, N.: aikakauskirja, 17 (1945), 11-18

Markerkarten für acht Chromosomen und erste QTL-Analyse an deutschen Milchrinder-Familien. Christian-Albrechts-Universität, Kiel, Germany, Thesis, 1997

Received: 2001-07-25

Accepted: 2002-08-02

Author's address

Dr. MUHAMED BRKA, PD Dr. NORBERT REINSCH,

Prof. Dr. Dr. h.c. mult. ERNST KALM

Institut für Tierzucht und Tierhaltung der Christian-Albrechts-Universität zu Kiel

Olshausenstr. 40

D-24098 Kiel

Germany 